\title{
Escherichia coli heat shock gene mutants are defective in proteolysis
}

\author{
David B. Straus, William A. Walter, and Carol A. Gross ${ }^{1}$ \\ Department of Bacteriology, University of Wisconsin at Madison, Madison, Wisconsin 53706 USA
}

\begin{abstract}
Heat shock proteins in Escherichia coli are relatively abundant and some are essential for growth, but the function that they provide is unknown. The observation that heat shock proteins are induced by some abnormal, rapidly degraded polypeptides, and that strains with mutations in the $\mathrm{rpoH}$ gene, the positive regulator of heat shock gene expression, are defective in proteolysis, has led to the proposal that heat shock proteins are required for normal degradation of polypeptides. We have investigated this hypothesis by examining the degradation of polypeptide fragments generated by puromycin and the degradation of a nonsense fragment of $\beta$-galactosidase. Mutations in the dnaK, dnaJ, grpE, and groEL heat shock genes result in defective proteolysis. Furthermore, overproduction of heat shock proteins results in enhanced rates of puromycyl fragment decay. The proteolysis defect of the heat shock gene mutants primarily affects energy-dependent protein degradation. These results indicate that at least one general function of heat shock proteins is to contribute to the ability of the cell to degrade abnormal polypeptides.
\end{abstract}

[Key Words: Heat shock proteins; Escherichia coli; proteolysis]

Received July 1, 1988; revised version accepted October 31, 1988.

When cells are shifted rapidly from low to high temperature, synthesis of the heat shock proteins is induced (Neidhardt et al. 1984; Craig 1985). Exposure to other stresses, such as ethanol, DNA-damaging agents, oxidizing conditions, some abnormal proteins, and viral infection also results in the induction of at least some heat shock proteins. This response is an apparently universal phenomenon, having been observed in all cell types examined, including examples from the archaebacterial, eubacterial, and eukaryotic kingdoms. The heat shock proteins are conserved. There is a high degree of similarity between the sequences of heat shock proteins from species as diverse an Escherichia coli, Drosophila melanogaster, and humans (Bardwell and Craig 1984; Mues et al. 1986). However, the function of heat shock proteins in the cell remains the subject of much speculation. We have investigated the function of several $E$. coli heat shock proteins by characterizing strains carrying mutations in heat shock genes.

The dnaK, dnal, grpE, groES, and groEL genes are among $\sim 20$ heat shock genes identified so far in $E$. coli (Neidhardt et al. 1984). These genes, initially identified because their gene products are required for the growth of bacteriophage $\lambda$, subsequently were shown to encode heat shock proteins. In addition to their effect on bacteriophage growth, mutations in these genes also confer a temperature-sensitive growth defect, indicating that these gene products are required for cell viability, at

${ }^{1}$ Corresponding author. least at high temperature. Although several of the heat shock proteins are among the most abundant in the cell, at both low and high temperature, their essential role in cell growth remains obscure.

Transcription of heat shock genes is controlled by an alternate sigma factor of RNA polymerase, $\sigma^{32}$, the product of the rpoH (htpR) gene (Grossman et al. 1984; Landick et al. 1984; Yura et al. 1984). Strains with a poorly suppressed amber mutation in $r p o H$ are defective in the heat shock response (Neidhardt and VanBogelen 1981; Yamamori et al. 1982). These strains also exhibit an altered capacity to degrade unstable or abnormal polypeptides (Baker et al. 1984; Goff et al. 1984). One possible explanation for this proteolytic defect would be the involvement of heat shock proteins in protein degradation. To investigate this hypothesis we characterized the ability of strains with mutations in the dnaK, dnaJ, grpE, groEL, or groES genes to degrade abnormal proteins. We compared the the proteolytic capacity of these mutants to that of an isogenic strain carrying a Tn10 $16 \Delta 17$ insertion in the lon gene (Maurizi et al. 1985). Ion is a heat shock gene (Phillips et al. 1984; Goff et al. 1984), encoding the well-characterized La protease (Goldberg et al. 1983).

\section{Results}

Degradation of puromycyl fragments

The addition of puromycin to bacterial cells actively synthesizing protein results in premature translation termination, generating unstable polypeptides. The rate 
Table 1. Puromycyl fragment degradation in heat shock gene mutants

\begin{tabular}{lclllll}
\hline $\begin{array}{l}\text { Rate of degradation } \\
\left({ }^{\circ} \mathrm{C}\right)\end{array}$ & Wild type & lon146 & dnaK756 & grpE280 & dnal259 & groEL140 \\
\hline 30 & 1 & $0.75 \pm 0.07$ & $0.67 \pm 0.08$ & $0.58 \pm 0.11$ & $0.35 \pm 0.04$ & $0.69 \pm 0.12$ \\
42 & 1 & $0.71 \pm 0.07$ & $0.73 \pm 0.07$ & $0.64 \pm 0.10$ & $0.54 \pm 0.09$ & $\mathrm{nt}$ \\
\hline
\end{tabular}

Puromycyl fragment experiments were carried out as described in Fig. 1 and Materials and methods. Cultures were grown at $30^{\circ} \mathrm{C}$, or grown at $30^{\circ} \mathrm{C}$ and shifted to $42^{\circ} \mathrm{C}$ for $10 \mathrm{~min}$ before treatment with puromycin and labeling with $\left[{ }^{35} \mathrm{~S}\right]$ methionine. The rate of release of TCA-soluble cpm during the first $30 \mathrm{~min}$ after the removal of puromycin and chase with excess unlabeled methionine was determined as a percent of total cpm incorporated. The rate of degradation for each strain was normalized to the rate of the wild-type strain. The rates represent the average fraction of the wild-type rate from at least four experiments \pm SE. (nt) Not tested.

of degradation of these polypeptides into acid-soluble products has been used to measure the ability of strains to carry out the degradation of abnormal proteins (Goldberg 1972).

We determined the rate of puromycyl fragment degradation at $30^{\circ} \mathrm{C}$, or $10 \mathrm{~min}$ following shift to $42^{\circ} \mathrm{C}$, in isogenic strains carrying the dnaK756, dnal259, grpE280 , groEL140, and groES30 temperature-sensitive mutations, or the lon $146::$ Tn 10 mutation. All of the heat shock gene mutants, with the exception of groES30 (data not shown), degrade puromycyl fragments more slowly than the isogenic wild-type strain. Figure 1 shows the release of $\left.{ }^{35} S\right]$ methionine incorporated in puromycyl

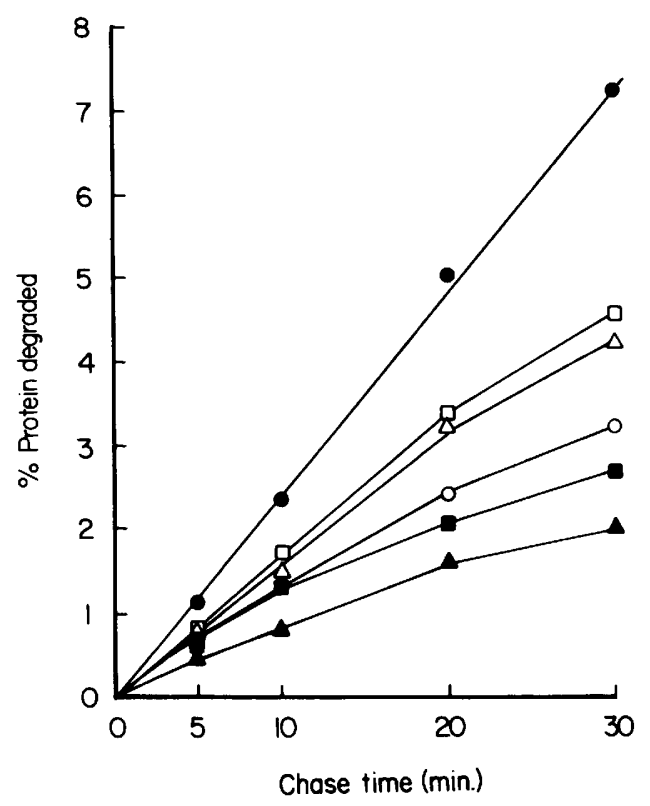

Figure 1. Protein degradation in wild-type and mutant strains at $30^{\circ} \mathrm{C}$ following puromycin treatment. Strains were grown in M9-glucose media supplemented with all amino acids except for methionine, treated with puromycin for $10 \mathrm{~min}$, labeled with $\left.{ }^{35} \mathrm{~S}\right]$ methionine for $3 \mathrm{~min}$, harvested, washed, and resuspended in media with excess unlabeled methionine. Aliquots were sampled into $10 \%$ TCA at $0,5,10,20$, and $30 \mathrm{~min}$ after the start of the chase. The percent of total incorporated cpm that became soluble in TCA was determined by liquid-scintillation counting as described in Materials and methods. Strains: (•) CAG9270 (wild type); (ㅇ) CAG9271 (dnaK756); (-) CAG9273

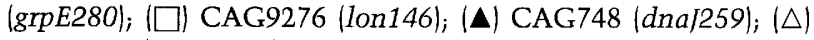
CAG9310 (groEL140). fragments, as a function of time after removal of puromycin, for each of the five defective mutants growing at $30^{\circ} \mathrm{C}$. A compilation of data on the initial rates of degradation in the mutants at $30^{\circ} \mathrm{C}$ and after shift to $42^{\circ} \mathrm{C}$, expressed as a fraction of the wild-type rate, is shown in Table 1. The dna/259 allele exhibited the greatest defect in proteolysis. The rate of degradation of puromycyl fragments in this strain was only $35 \%$ of normal at $30^{\circ} \mathrm{C}$ (Fig. 1; Table 1). The other strains, dnaK756, grpE280, and groEL140 were approximately as defective as the lon146 :: Tn10 strain, exhibiting rates of degradation between $60 \%$ and $75 \%$ of normal (Fig. 1; Table 1). The rate of puromycyl fragment degradation in wild-type cells increased approximately threefold after temperature shift, but the mutants had the same affect on proteolysis at $42^{\circ} \mathrm{C}$ relative to the wild-type strain as they did at $30^{\circ} \mathrm{C}$ (Table 1). The only exception to this was the dna/259 strain, which exhibited a less severe defect after shift to $42^{\circ} \mathrm{C}$ than at $30^{\circ} \mathrm{C}$ (Table 1).

\section{Degradation of the lacZX90 polypeptide}

To characterize proteolysis further in the heat shock gene mutants, we examined the degradation of a specific unstable protein. The lacZX-90 allele has a nonsense mutation late in the $1 a c Z$ gene that results in the synthesis of an unstable polypeptide (Bukari and Zipser 1973). In wild-type cells the X-90 protein is degraded with a half-life of $\sim 20 \mathrm{~min}$ at $30^{\circ} \mathrm{C}$. After shift to $42^{\circ} \mathrm{C}$ the half-life of X-90 is only $4 \mathrm{~min}$. (Fig. 2).

Four of the heat shock gene mutants, dnaK756, dna/259, grpE280, and lon146 :: Tn10 alter the degradation of X-90. At high temperature these mutants were defective in the degradation of X-90 polypeptide, increasing the half-life as much as 25 -fold (Fig. 2A). At $30^{\circ} \mathrm{C}$ the mutants exhibited two distinct alterations in X-90 degradation (Fig. 2B). In the dnal259 strain, as has been reported previously for lon strains, the unstable protein was degraded more slowly than in the wild-type strain. However, in the dnaK756 and grpE280 strains $\mathrm{X}-90$ was degraded three- or fourfold faster than in the isogenic wild-type strain. A hyperdegradation phenotype has been observed previously for the degradation of the $\lambda$ cII protein in lon strains and may indicate that defects in one proteolytic pathway enhance the activity of other pathways (Gottesman et al. 1981). The groEL140 and groES30 alleles had no effect on X-90 degradation (data not shown). 
A.

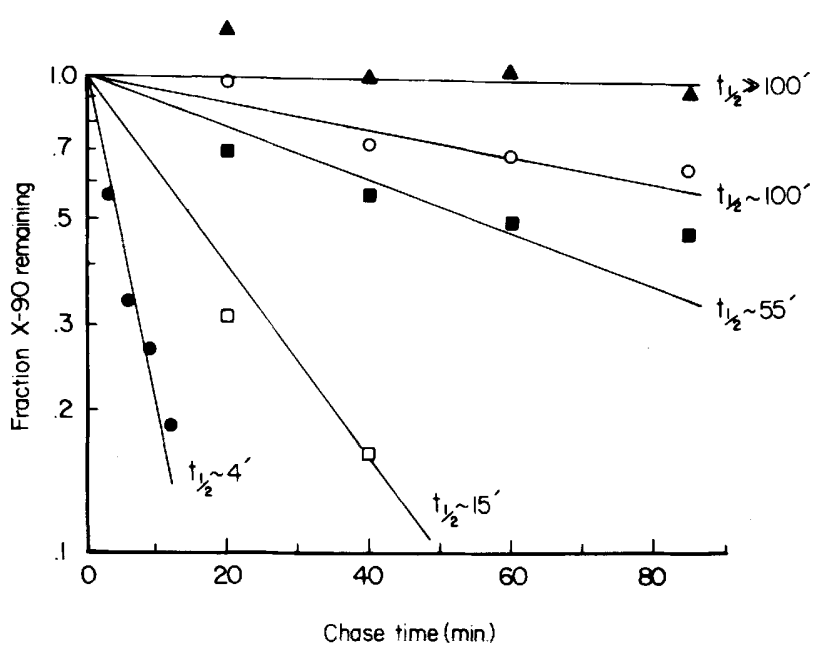

B. $30^{\circ}$

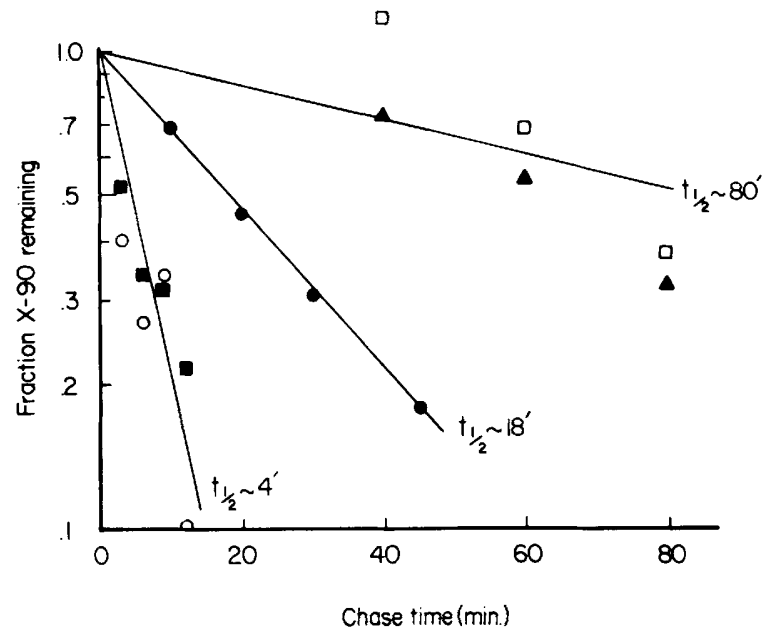

Figure 2. Degradation of the X-90 polypeptide in wild-type and mutant strains at $42^{\circ} \mathrm{C}$ and $30^{\circ} \mathrm{C}$. Cultures were induced with $1 \mathrm{mM}$ IPTG for $20 \mathrm{~min}$ and then pulse-labeled with $\left.{ }^{35} S\right]$ methionine. At various times after the addition of excess unlabeled methionine, aliquots were sampled into TCA and the amount of labeled X-90 polypeptide remaining was determined by immunoprecipitation as described in the Materials and methods. (A) Strains were grown at $30^{\circ} \mathrm{C}$, induced with IPTG, and then shifted to $42^{\circ} \mathrm{C}$ for 5 min prior

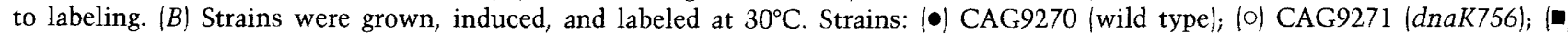
CAG9273 (grpE280); (口) CAG9276 (lon146); (A) CAG748 (dna)259).

\section{Degradation of puromycyl fragments in strains with increased amounts of heat shock proteins}

We examined the effect of enhanced heat shock protein function on protein degradation by measuring the proteolytic capacity of cells that had an elevated concentration of heat shock proteins. Synthesis of heat shock proteins can be induced without a temperature upshift if $\sigma^{32}$ is overproduced artificially using a plasmid that places transcription of $r p o H$ under control of the inducible tac promoter (Grossman et al. 1987). Using strains with this plasmid, we determined the degradation rate of puromycyl fragments in cells growing at $30^{\circ} \mathrm{C}$ after the induction of $\sigma^{32}$ by the addition of isopropyl thiogalactoside (IPTG). The results show that overproduction of heat shock proteins leads to a more rapid rate of degradation (Fig. 3A). In addition, the higher rate of puromycyl fragment decay that is observed normally after shift to $42^{\circ} \mathrm{C}$ is not a maximum because it can be enhanced further by artificially overproducing heat shock proteins (Fig. 3B). These results indicate that the degradation of puromycyl fragments is limited by the intracellular concentration of heat shock proteins.

Goff and Goldberg (1987) demonstrated that increased dosage or expression of the lon heat shock gene, encoding the La protease, results in increased rates of protein degradation. To distinguish the effect of increasing the concentration of $\mathrm{La}$ from effects of increasing the concentration of other heat shock proteins, the overproduction experiment was also performed with an isogenic strain carrying the lon $146:: \operatorname{Tn} 10$ allele. The results show that enhanced degradation of puromycyl frag- ments following overproduction of heat shock proteins can occur without a functional La protease (Fig. 3A,B).

\section{Energy-dependent proteolysis in the heat shock gene mutants}

Degradation of puromycyl fragments is partially energy dependent (Goldberg 1972). The removal of glucose, and the addition of potassium cyanide to block respiration, causes depletion of ATP pools and reduction of puromycyl fragment decay by $70-80 \%$. This inhibition is not the result of cell death because reversal of these conditions restores proteolysis to normal rates (Goldberg 1972; Maurizi et al. 1985). Removing glucose and adding cyanide to the $d n a K, g r p E, d n a I$, and groEL mutants results in a reduction in puromycyl fragment degradation to the same rate observed for the wild-type strain following this treatment (Fig. 4). Since the effects of the mutant alleles and depletion of ATP on puromycyl fragment degradation are not additive it is likely that the heat shock gene products are involved primarily in energy-dependent protein degradation.

\section{Discussion}

Our results provide two lines of evidence indicating that a number of the heat shock proteins are involved in protein degradation in E. coli. First, the overproduction of heat shock proteins, without a temperature shift, results in enhanced rates of puromycyl fragment decay. This result not only implies a role for heat shock proteins in proteolysis, but also suggests that when there is an 
abundance of unstable polypeptides the proteolytic capacity of the cell may be limited by the expression of heat shock genes. Second, we show that the DnaK, DnaJ, GrpE, and GroEL heat shock proteins in particular, as well as the previously identified La protease, are required for normal cellular proteolysis. Strains with mutations in dnaK, dnaI, grpE, groEL, or lon are defective in the degradation of peptides generated by puromycin, and except for the groEL strain, are also defective in the degradation of an unstable nonsense fragment of $\beta$-galactosidase, X-90. Mutations in $\operatorname{dn} a K, \operatorname{dnaI}$, and grpE genes are also defective in the degradation of $\sigma^{32}$ (D. Straus and C. Gross, in prep.). Our results may underestimate the extent to which heat shock protein function is required for proteolysis since, with the exception of lon 146, it is not certain that the mutants completely lack gene product function. Keller and Simon (1988) have also determined that a dnaK mutant is defective in the degradation of puromycyl fragments, canavanyl peptides, and a temperature-sensitive lacI gene product.

A.

$30^{\circ}$

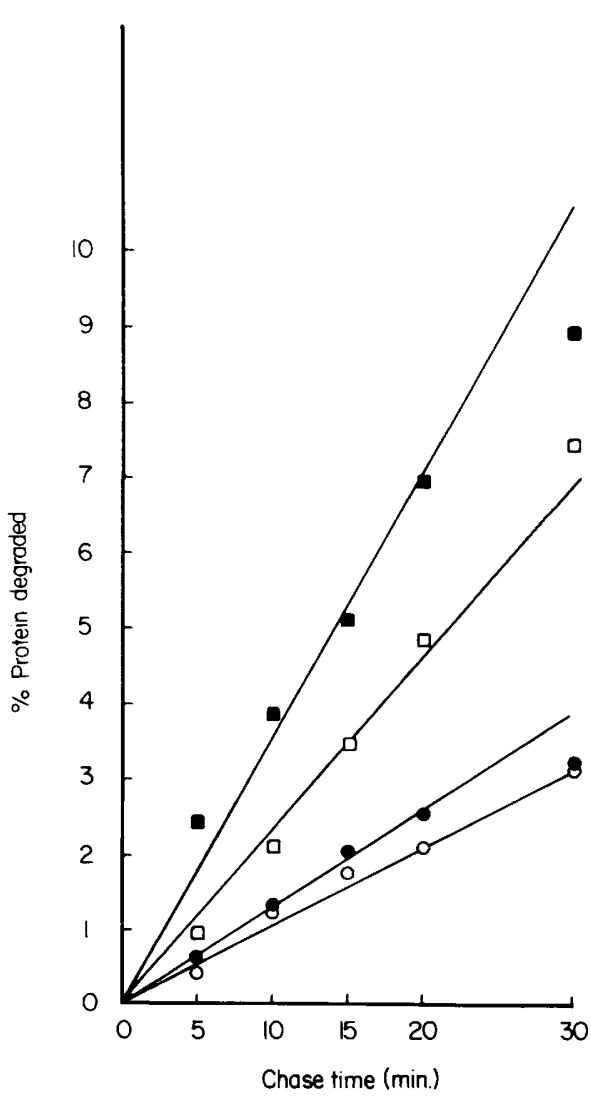

All the mutants primarily affect energy-dependent proteolysis. The lack of additivity of the inhibitory affects of the mutants and potassium cyanide on puromycyl fragment degradation implies that the mutants alter energy-dependent, rather than energy-independent, protein degradation. Even the dnal mutant, which exhibits almost as severe an inhibition of puromycyl fragment degradation as the addition of cyanide, has little effect on energy-independent degradation. The defect in energy-dependent degradation in the mutants may indicate an important role for the ATPase or nucleotidase activities that have been observed with purified GroEL (Hendrix 1979) and DnaK proteins (Zylicz et al. 1983).

The dnaK, grpE, dnal, groEL, and lon gene products need not represent five distinct proteolytic activities because a number of them could interact. It is likely that DnaK and GrpE function together. The dnaK and grpE mutants exhibit parallel proteolysis phenotypes. Mutations in both genes increase the degradation of X90 at $30^{\circ} \mathrm{C}$ while stabilizing it at $42^{\circ} \mathrm{C}$, and mutations in both
B.

$42^{\circ}$

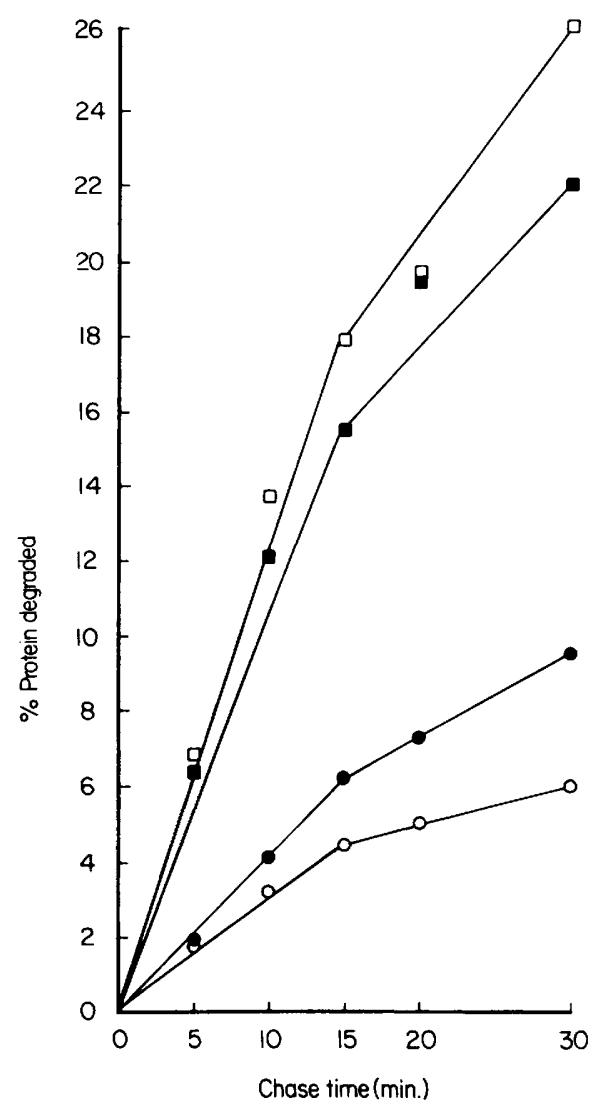

Figure 3. Protein degradation in the presence of excess heat shock proteins in wild-type and lon 146 strains at $30^{\circ} \mathrm{C}$, and after shift to $42^{\circ} \mathrm{C}$, following treatment with puromycin. Strains carrying either plasmid pDS2 (Ptac-rpoH) or the vector, pKK223, were induced with IPTG for $15 \mathrm{~min}$, treated with puromycin, labeled with $\left[{ }^{35} \mathrm{~S}\right]$ methionine, washed, and chased with excess unlabeled methionine. (A) Cultures were grown at $30^{\circ} \mathrm{C} ;(B)$ cultures were grown at $30^{\circ} \mathrm{C}$ and then shifted to $42^{\circ} \mathrm{C}$ and induced with IPTG simultaneously.

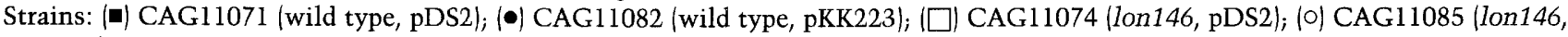
pKK223). 


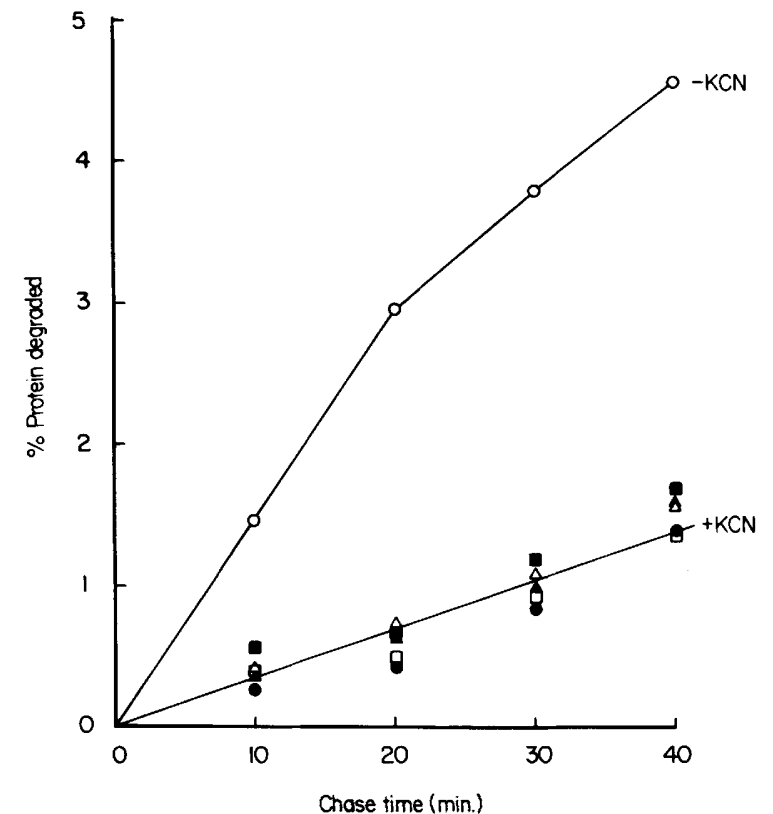

Figure 4. Energy-independent protein degradation in wild-type and mutant strains at $30^{\circ} \mathrm{C}$ following treatment with puromycin. Strains were treated with puromycin and labeled with $\left.{ }^{35} \mathrm{~S}\right]$ methionine as described in Materials and methods. Cell were washed to remove puromycin and unincorporated label and then resuspended in media without glucose containing excess unlabeled methionine and $1 \mathrm{mM} \mathrm{KCN}$. Cultures were incubated at $30^{\circ} \mathrm{C}$ for $20 \mathrm{~min}$ to deplete energy stores before sampling to determine the percent of total incorporated cpm that became acid-soluble. One wild-type culture was not treated with KCN, CAG9270 (ㅇ). Cultures treated with KCN are: (•)

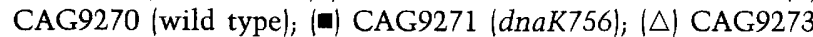
(grpE280); ( $\square$ ) CAG748 (dna)259); (A) CAG9310 (groEL140).

genes decrease the rate of degradation of puromycyl fragments. This conclusion is consistent with biochemical data which shows that GrpE can bind specifically to DnaK in a ATP-dependent manner (Zylicz et al. 1987). Although there is no evidence that GroEL interacts specifically with any of the other heat shock proteins involved in proteolysis, Dnal may interact functionally with GrpE and DnaK. All three proteins are involved in the initiation of bacteriophage $\lambda$ replication (Saito and Uchida 1977; Dodson et al. 1986; C. Alfano and R. McMaken, pers. comm.), and a dnal strain is defective in phosphorylation of some of the same proteins as a dnaK strain (Wada et al. 1986). The proteolysis phenotype of the dnaI mutant though is distinct from grpE and dnaK. The X90 polypeptide is stabilized in the dnaJ259 mutant at $30^{\circ} \mathrm{C}$ but degraded at rates greater than normal in the other two mutants, suggesting that these heat shock proteins are involved in at least two different degradative pathways.

It is unlikely that the proteolytic defects that have been described can be attributed solely to the activity of the lon protease. Puromycyl fragment degradation in the dnal strain and $\mathrm{X} 90$ degradation at $42^{\circ} \mathrm{C}$ in the $d n a K$, $d n a I$, and grpE strains are more defective than in the lon insertion mutant, suggesting that at least one other proteolytic system is altered. In addition, the hyperdegradation of the $\mathrm{X} 90$ polypeptide at $30^{\circ} \mathrm{C}$ in the $d n a K$ and $g r p E$ mutants is qualitatively distinct from the stabilization phenotype of the lon mutant. The phenotype of the dnaK and grpE strains cannot be explained by an increase in lon activity despite the increased degradation rate of $\mathrm{X} 90$ at $30^{\circ} \mathrm{C}$ because these strains also exhibit a decrease in puromycyl fragment degradation at $30^{\circ} \mathrm{C}$. Examination of a dnaK, lon double mutant supports the conclusion that two distinct proteolytic systems are affected in such a strain (Keller and Simon 1988; D. Straus and C. Gross, unpubl.). Furthermore, increased rates of proteolysis are observed following overproduction of heat shock proteins even in strains containing a lon null allele. These results do not eliminate the possibility that heat shock proteins alter lon activity, but they do suggest that probably several other proteolytic systems are affected by the action of these proteins.

Investigations of heat shock proteins have led to the proposal that their general function is to control the higher-order structure of proteins present either as individual polypeptides or in multicomponent assemblies (Pelham 1986; Hemmingsen et al. 1988). Specifically, Pelham (1986) has proposed that eukaryotic HSP70 and related proteins, which are highly homologous to DnaK, use ATP to alter the conformation of target proteins to prevent aggregation and/or allow refolding of the polypeptide. For example, an HSP70 cognate protein has been shown to catalyze the ATP-dependent removal of clathrin from clathrin-coated vesicles /Chappell et al. 1986). A subgroup of the yeast hsp70 proteins is required for post-translational transport of at least some proteins across mitochondrial and endoplasmic reticulum membranes (Deshaies et al. 1988; Chirico et al. 1988). These hsp70 proteins are proposed to function as ATP-dependent 'unfoldases', maintaining the transported protein in an open conformation required for post-translational transport. Glucose-regulated proteins related to HSP70, present in the endoplasmic reticulum of mammalian cells, have been shown to bind incorrectly folded polypeptides (Gething et al. 1986; Kassenbrock et al. 1988), as well as immunoglobulin heavy-chain peptides prior to their assembly with immunoglobulin light chains (Bole et al. 1986). These examples suggest that HSP70 proteins have a variety of functions all using the ability to control protein conformation or protein-protein interactions.

The involvement of $E$. coli heat shock proteins in proteolysis is consistent with the above proposal because it is likely that they play a structural rather than catalytic role in this process, and their effect is energy dependent. The only E. coli heat shock protein known to be involved directly in protein degradation is the ATP-dependent protease encoded by lon (Goldberg et al. 1983). The possibility that GroEL, DnaK, DnaJ, and GrpE might be proteases has not been tested in vitro, but the fact that GroEL and DnaK represent as much as $3 \%$ of total cell protein at $37^{\circ} \mathrm{C}$ (Neidhardt et al. 1984) suggests a structural role for at least these two proteins. Investigations into the function of $E$. coli heat shock proteins in bacte- 
riophage growth support this conclusion. GroEL, in conjuction with GroES, is required for the assembly of bacteriophage $\lambda$ head structures (Georgopoulos et al. 1973) and T4 head structures (Georgopoulos et al. 1972; Coppo et al. 1973), including proteolytic processing, and also the assembly of bacteriophage T5 tail structures (Zweig and Cummings 1973). DnaK, Dnal, and GrpE are involved in the disaggregation of a specialized nucleoprotein structure present at the replication origin of the $\lambda$ genome (Dodson et al. 1986; C. Alfano and R. McMaken, pers. comm.). These proteins disrupt the DnaB- $\lambda$ P protein interaction permitting the consequent activation of the helicase activity of $\mathrm{DnaB}$ required to initiate $\lambda$ DNA replication. By analogy with their role in bacteriophage development, and the apparent function of eukaryotic heat shock proteins, DnaK, GrpE, DnaJ, and GroEL probably provide a structural requirement for proteolysis. Proteolysis could be facilitated by heat shock proteins if they prevented the aggregation of substrate molecules by binding to them, or actively altered the conformation of the substrate, utilizing ATP hydrolysis, to make it more susceptible to proteolysis. Alternatively, the heat shock proteins may affect proteolysis by interacting with proteolytic enzymes. Mutations in heat shock genes may cause defects in protein degradation because the protein surfaces used during these interactions are altered or inactivated. Although other diverse phenotypes associated with mutations in heat shock genes could result from defects in proteolysis, they may, instead, be the result of additional heat shock protein functions which use a general ability to control higher-order protein structure.

The presence of abnormal proteins is one of the conditions that induces the heat shock response (Kelly and Schlesinger 1978; Goff and Goldberg 1985; Ananthan et al. 1986). This correlation has led a number of investigators to propose that the signal for heat shock is an abundance of abnormal proteins that can saturate the proteolytic capacity of the cell and competitively inhibit degradation of heat shock gene regulatory molecules (Finley et al. 1984; Goff and Goldberg 1985; Ananthan et al. 1986). Because heat shock proteins have been implicated in the turn-off of the response (DiDomenico et al. 1982; Tilly et al. 1983), an important corollary of this proposal is that heat shock proteins are involved in the elimination or stabilization of abnormal peptides so that the signal for the response is removed. Our results support this model in that a number of heat shock genes in E. coli, beside lon, have been identified now as required for normal protein degradation. In particular, our results indicate that when there is an abundance of unstable polypeptides, following treatment with puromycin, the rate of proteolysis is limited by the concentration of heat shock proteins. These results provide important support for this model of heat shock induction. However, because heat shock proteins may be involved in a variety of functions besides protein degradation, the signal for the heat shock response could be controlled by a heat shock protein function that is not related directly to proteolysis.

\section{Materials and methods}

\section{Strains}

All strains are derivatives of $\mathrm{C} 600$; thi thr leu tonA supE lacYlacZX-90. Strains CAG9270, CAG9271, CAG9273, CAG9276, CAG748, CAG9259, and CAG9310 are also F'lacZX-90 with thr :: Tn10, dnaK756-thr :: Tn10, grpE280-tyrA :: Tn10,

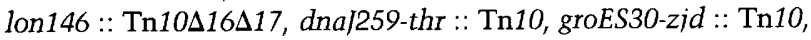
and groEL140-zjd:: Tn10 alleles, respectively. These alleles were transduced into this background using Plvir, selecting for tetracycline resistance, and scoring for either mucoidy, in the case of lon, or temperature sensitivity in the case of the other alleles. C. Georgopolous kindly supplied strains containing the dnaK756, dnaI259, grpE280, groES30, and groEL140 alleles. S.

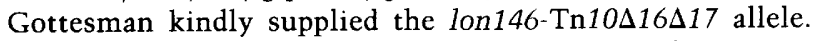
CAG11071 and CAG11082 are C600 with $\mathrm{F}^{\prime} l a c I^{q}, \operatorname{lacZ}::$ Tn5 and plasmid pDS2 or pKK223-3, respectively. CAG11074, and CAG11085 are the corresponding lon $146::$ Tn 10 derivatives of CAG11071 and CAG1 1082. Plasmid pDS2 has the tac promoter directing expression of rpoH (Grossman et al. 1987), and pKK223-3 (Pharmacia) is the vector used for the construction of pDS2.

\section{Puromycyl fragment degradation}

Analysis of puromycyl fragment degradation was performed essentially as described (Goldberg 1972). Strains were grown in a shaking water bath to mid-log phase in M9-glucose medium supplemented with vitamins and all amino acids except for methionine. Aliquots of cell culture were treated with puromycin $(0.1 \mathrm{mg} / \mathrm{ml})$ for $10 \mathrm{~min}$, then labeled with $\left[{ }^{35} \mathrm{~S}\right]$ methionine $(\sim 3$ $\mu \mathrm{Ci} / \mathrm{ml}$ ) for $3 \mathrm{~min}$. Cells were harvested, washed twice, resuspended at the initial cell density in media containing $200 \mu \mathrm{g} / \mathrm{ml}$ unlabeled methionine, and then returned to the pretreatment growth conditions. In experiments examining energy-independent degradation, cells were washed in media containing 200 $\mu \mathrm{g} / \mathrm{ml}$ methionine but lacking glucose and resuspended in the same media lacking glucose either with or without $1 \mathrm{mM} \mathrm{KCN}$ (Maurizi et al. 1985). At various times following removal of puromycin and unincorporated $\left[{ }^{35} \mathrm{~S}\right]$ methionine, aliquots were sampled into $10 \%$ trichloroacetic acid (TCA) on ice, with 200 $\mu \mathrm{g}$ bovine serum albumin as carrier. Samples were centrifuged and the supernatant was analyzed by liquid-scintillation counting to determine the TCA-soluble cpm. An aliquot of cell culture, which had been pulse-labeled and washed, was counted directly to estimate the total $\mathrm{cpm}$ incorporated. The data is expressed as the percent of total cpm incorporated that is soluble in $10 \% \mathrm{TCA}$ as a function of time after removal of puromycin. The background of TCA-soluble $\mathrm{cpm}$ present at $0 \mathrm{~min}$ of the chase is subtracted from the TCA-soluble $\mathrm{cpm}$ values at later chase times. Puromycin incorporation was approximately the same in all strains as assayed by inhibition of synthesis of the $\beta$ and $\beta^{\prime}$ subunits of RNA polymerase.

\section{LacZX-90 degradation}

LacZX-90 degradation rates were determined by pulse-labeling and immunoprecipitation. Strains were grown to mid-log phase in M9-glycerol medium with vitamins and all amino acids except methionine. Synthesis of X-90 was induced with IPTG (1 $\mathrm{mM}$ ) for $20 \mathrm{~min}$, cultures were labeled with ${ }^{35} \mathrm{~S}$ ] methionine (10 $\mu \mathrm{Ci} / \mathrm{ml}$ ) for $3 \mathrm{~min}$, and then chased with unlabeled methionine $(1 \mathrm{mg} / \mathrm{ml})$. At various times after the start of the chase, aliquots were added directly to an equal volume of $10 \%$ TCA. The precipitate was collected by centrifugation and was washed exten- 
sively with cold $80 \%$ acetone before drying under vacuum and resuspension in $2 \%$ SDS, $50 \mathrm{~mm}$ Tris $(\mathrm{pH} 7.5)$. To correct for losses during the quantitation of $\mathrm{X}-90$, each sample received an equal amount of a cell extract containing ${ }^{3} \mathrm{H}$-labeled $\beta$-galactosidase. The $\beta$-galactosidase polypeptides were immunoprecipitated using antiserum (supplied by B. Rotman) that had been adsorbed with a cell extract from a lac deletion strain. The immunoprecipitates were analyzed on an SDS-polyacrylamide gel, and gel slices containing the full-length polypeptides were excised (X-90 and $\beta$-galactosidase comigrate), solubilized, and counted. The data is expressed as the fraction of X-90 initially present as a function of time after the start of the chase.

\section{Acknowledgments}

We would like to thank Costa Georgopoulos and Susan Gottesman for kindly providing strains, Alan Grossman for advice and discussions, and Jim Erickson for comments on the manuscript. The work described was supported by a grant from the National Institutes of Health (R01 GM-36278).

\section{References}

Ananthan, J., A. Goldberg, and R. Voellmy. 1986. Abnormal proteins serve as eukaryotic stress signals and trigger the activation of heat shock genes. Science 232: 522-524.

Baker, T.A., A.D. Grossman, and C.A. Gross. 1984. A gene regulating the heat shock response in $E$. coli affects proteolysis. Proc. Natl. Acad. Sci. 81: 6779-6783.

Bardwell, J.C.A. and E.A. Craig. 1984. Major heat shock gene of Drosophila and the Escherichia coli heat-inducible dnaK gene are homologous. Proc. Natl. Acad. Sci. 81: 848-852.

Bole, D.G., L.M. Hendershot, and J.F. Kearney. 1986. Posttranslational association of immunoglobulin heavy chain binding protein with nascent heavy chains in nonsecreting and secreting hybridomas. J. Cell Biol. 102: 1558-1566.

Bukari, A.I. and D. Zipser. 1973. Mutants of Escherichia coli with a defect in the degradation of nonsense fragments. $\mathrm{Na}$ ture 243: 238-241.

Chappell, T.G., W.J. Welch, D.M. Schlossmann, K.B. Palter, M.J. Schlessinger, and J.E. Rothman. 1986. Uncoating ATPase is a member of the 70 kilodalton family of stress proteins. Cell 45: 3-13.

Chirico, W.J., M.G. Water, and G. Blobel. 1988. 70K heat shock related proteins stimulate protein translocation into microsomes. Nature 332: 805-810.

Coppo, A., A. Manzi, J. Pulitzer, and H. Takahashi. 1973. Abortive bacteriophage T4 head assembly in mutants of Escherichia coli. J. Mol. Biol. 76: 61-87.

Craig, E.A. 1985. The heat shock response. Crit. Rev. Biochem. 18: $239-280$.

Deshaies, R.J., B.D. Koch, M. Werner-Washburne, E.A. Craig, and R. Schekman. 1988. A subfamily of stress proteins facilitates translocation of secretory and mitochondrial precursor polypeptides. Nature 322: 800-805.

DiDomenico, B.J., G.E. Bugaisky, and S. Lindquist. 1982. The heat shock response is self-regulated at both the transcriptional and post-transcriptional levels. Cell 31: 593-603.

Dodson, M., H. Echols, S. Wickner, C. Alfano, K. Mensa-Wilmont, B. Gomes, J. LeBowitz, J. Roberts, and R. McMaken. 1986. Specialized nucleoprotein structures at the origin of bacteriophage lambda: Localized unwinding of DNA by a six-protein reaction. Proc. Natl. Acad. Sci. 83: 7638-7642.

Finley, D., A. Ciechanover, and A. Varshavsky. 1984. Thermo- lability of the ubiquitin-activating enzyme from the mammalian cell cycle mutant ts85. Cell 37: 43-55.

Georgopoulos, C., R. Hendrix, A. Kaiser, and W. Wood. 1972. Role of the host cell in bacteriophage morphogenesis: Effects of a bacterial mutation on T4 head assembly. Nat. New Biol. 239: 38-41.

Georgopoulos, C.G., R.W. Hendrix, S.R. Casjens, and A.D. Kaiser. 1973. Host participation in bacteriophage lambda head assembly. J. Mol. Biol. 76: 45-60.

Gething, M., K. McCammon, and J. Sambrook. 1986. Expression of wild-type and mutant forms of influenza hemagglutinin: The role of folding in intracellular transport. Cell 46: 939-950.

Goff, S.A. and A.L. Goldberg. 1985. Production of abnormal proteins in E. coli stimulates transcription of lon and other heat shock genes. Cell 41: 587-595.

- 1987. An increased content of protease $\mathrm{La}$, the lon gene product, increases protein degradation and blocks growth in Escherichia coli. J. Biol. Chem. 262: 4508-4515.

Goff, S.A., L.P. Casson, and A.L. Goldberg. 1984. The heat shock regulatory gene, $h t p R$, influences rates of protein degradation and expression of the lon gene in Escherichia coli. Proc. Nat1. Acad. Sci. 81: 6647-6651.

Goldberg, A.L. 1972. Degradation of abnormal proteins in Escherichia coli. Proc. Natl. Acad. Sci. 69: 422-426.

Goldberg, A.L., K.H. Sreedhara Swamy, C.H. Chung, and F.S. Larimore. 1983. Proteases of Escherichia coli. Methods Enzymol. 80: 680-702.

Gottesman, S., M. Gottesman, J. Shaw, and M. Pearson. 1981. Protein degradation in E. coli: The lon mutation and bacteriophage lambda $\mathrm{N}$ and cII protein stability. Cell 24: 225233.

Grossman, A.D., J.W. Erickson, and C.A. Gross. 1984. The htpR gene product of $E$. coli is a sigma factor for heat-shock promoters. Cell 38: 383-390.

Grossman, A.D., D.B. Straus, W.A. Walter, and C.A. Gross. 1987. $\sigma 32$ synthesis can regulate the synthesis of heat shock proteins in Escherichia coli. Genes Dev. 1: 179-184.

Hemmingsen, S.M., C. Woolford, S.M. van der Vies, K. Tilly, D.T. Dennis, C.P. Georgopoulos, R.W. Hendrix, and R.J. Ellis. 1988. Homologous plant and bacterial proteins chaperone oligomeric protein assembly. Nature 333: 330-334.

Hendrix, R.W. 1979. Purification and properties of GroE, a host protein involved in bacteriophage assembly. I. Mol. Biol. 129: 375-392.

Kassenbrock, C.K., P.D. Garcia, P. Walter, and R.B. Kelly. 1988. Heavy-chain binding protein recognizes aberrant polypeptides translocated in vitro. Nature 333: 90-93.

Keller, I.A. and L.D. Simon. 1988. Divergent effects of a dnaK mutation on abnormal protein degradation in Escherichia coli. Mol. Micro. Biol. 2: 31-41.

Kelly, P.M. and M.J. Schlesinger. 1978. The effect of amino acid analogues and heat shock on gene expression in chicken embryo fibroblasts. Cell 15: 1277-1286.

Landick, R., V. Vaughn, E.T. Lau, R.A. VanBogelen, J.W. Erickson, and F.C. Neidhardt. 1984. Nucleotide sequence of the heat shock regulatory gene of $E$. coli suggests its protein product may be a transcription factor. Cell 38: 175-182.

Maurizi, M., P. Trisler, and S. Gottesman. 1985. Insertional mutagenesis of the lon gene in Escherichia coli: lon is dispensable. I. Bacteriol. 164: 1124-1135.

Mues, G.I., T.Z. Munn, and J.D. Raese. 1986. A human gene family with sequence homology to Drosophila melanogaster HSP7O heat shock genes. I. Biol. Chem. 261: 874877.

Neidhardt, F.C. and R.A. VanBogelen. 1981. Positive regulatory 
gene for temperature-controlled proteins in Escherichia coli. Biochem. Biophys. Res. Commun. 100: 894-900.

Neidhardt, F.C., R.A. VanBogelen, and V. Vaughn. 1984. Genetics and regulation of heat shock proteins. Annu. Rev. Genet. 18: 295-329.

Pelham, H.R.B. 1986. Speculations on the functions of the major heat shock and glucose-regulated proteins. Cell 46: $959-961$.

Phillips, T.A., R.A. VanBogelen, and F.C. Neidhardt. 1984. lon gene product of Escherichia coli is a heat shock protein. $J$. Bacteriol. 159: 283-287.

Saito, H. and H. Uchida. 1977. Initiation of the DNA replication of bacteriophage lambda in Escherichia coli K12. J. Mol. Biol. 113: 1-25.

Tilly, K., N. Mckittrick, M. Zylicz, and C. Georgopoulos. 1983. The dnaK protein modulates the heat shock response of Escherichia coli. Cell 34: 641-646.

Wada, M., K. Sekine, and H. Itikawa. 1986. Participation of the $d n a K$ and $d n a$ l gene products in phosphorylation of glutaminyl-tRNA synthetase and threonyl-tRNA synthetase in Escherichia coli K12. I. Bacteriol. 168: 213-220.

Yamamori, T., T. Osawa, T. Tobe, K. Ito, and T. Yura. 1982. Escherichia coli gene (hin) controls transcription of heatshock operons and cell growth at high temperature. In Heat shock from bacteria to man (ed. M. Schlesinger, M. Ashburner, and A. Tissieres), pp. 131-137. Cold Spring Harbor Laboratory, Cold Spring Harbor, New York.

Yura, T., T. Tobe, K. Ito, and T. Osawa. 1984. Heat-shock regulatory gene (htpR) or Escherichia coli is required for growth at high temperature but is dispensable at low temperature. Proc. Natl. Acad. Sci. 81: 6803-6807.

Zweig, M. and D. Cummings. 1973. Cleavage of head and tail proteins during bacteriophage $\mathrm{T} 5$ assembly: selective host involvement in the cleavage of a tail protein. $J$. Mol. Biol. 80: $505-518$.

Zylicz, M., D. Ang, and C. Georgopoulos. 1987. The grpE protein of Escherichia coli. J. Biol. Chem. 262: 17437-17442.

Zylicz, M., J. LeBowitz, R. McMaken, and C. Georgopoulos. 1983. The dnaK protein of Escherichia coli possesses an ATPase and autophosphorylating activity and is essential in an in vitro DNA replication system. Proc. Natl. Acad. Sci. 80: $6431-6435$. 


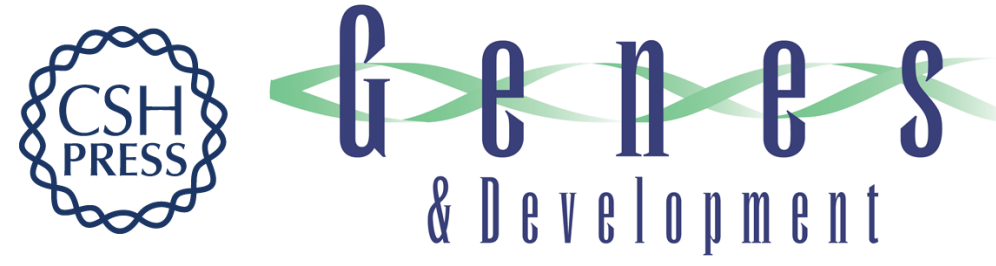

\section{Escherichia coli heat shock gene mutants are defective in proteolysis.}

D B Straus, W A Walter and C A Gross

Genes Dev. 1988, 2:

Access the most recent version at doi:10.1101/gad.2.12b.1851

References This article cites 43 articles, 16 of which can be accessed free at:

http://genesdev.cshlp.org/content/2/12b/1851.full.html\#ref-list-1

License

Email Alerting

Service

Receive free email alerts when new articles cite this article - sign up in the box at the top right corner of the article or click here.

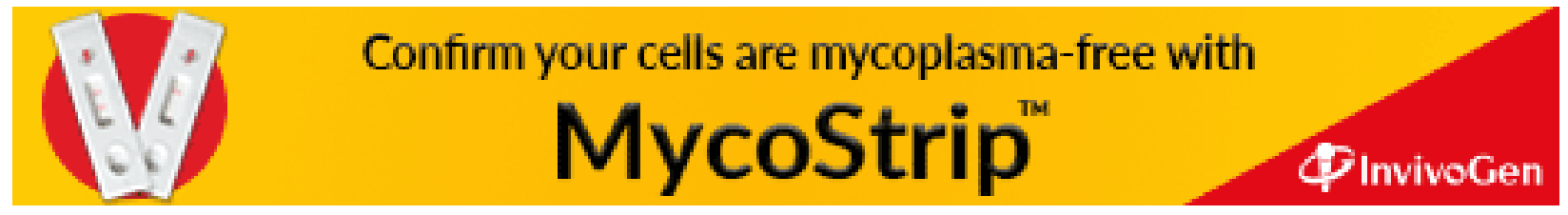

